\title{
Lexico-grammatical Analysis of AdaOkere Agbasimalo's The Forest Dames
}

Goodluck C. Kadiri, Asadu Emmanuela Uzoma*, Joekin Ekwueme

Department of English \& Literary Studies, University of Nigeria, Nsukka, Enugu State, Nigeria

Corresponding Author: Asadu Emmanuela Uzoma, E-mail: emmanuela.asadu@unn.edu.ng

\section{ARTICLE INFO}

Article history

Received: April 11, 2018

Accepted: July 18, 2018

Published: November 01, 2018

Volume: 7 Issue: 6

Advance access: September 2018

Conflicts of interest: None

Funding: None

\begin{abstract}
The importance of language in literary discourse can never be over-emphasized. Halliday and Matthiessen (2014), in broad terms, contend that language is used to carry out interpersonal functions in speech and writing. Hence, literary writers use language creatively to communicate their intended messages to their readers. This study, therefore, explores the lexico-grammatical assessment of AdaOkere Agbasimalo's The Forest Dames. The study aimed at identifying the prevalent linguistic tools deployed in the novel by the author, as a style index, for plot and theme developments. Also, to discuss logically how these tools contribute to project meanings in the novel. The study adopts Leech and Short's checklist of linguistic and stylistic categories as its analytical tool. Data were extracted randomly from the novel and analyzed qualitatively at levels of lexis and structure using the checklist. The findings revealed that the authors deployed more of the major parts of speech; military registers; code mixing and switching and pidginized word/ expressions to express the theme of hostility and futility of war. Also, at the grammatical level, sentences according to structure and function; inverted and elliptical sentences; adverbial and adjectival clauses were also used to expresses various themes and to develop the plots of the novel logically. It was concluded that Agbasimalo is a writer who used English creatively to express the consequences of Nigerian civil war on women and children. Conversely, it was suggested that scholars should conduct further studies on other aspects not covered in this research.
\end{abstract}

Key words: Lexico-grammar, Stylistics, Checklist, Linguistic Analysis, African Prose Fiction

\section{INTRODUCTION}

Language is as important to man as life itself is. No wonder Sapir (1921) and Robins (1980) describe it as a purely human and non- instinctive method of communicating ideas, emotions and desires by the means of voluntarily produced symbol. Language is, therefore, human specific and the vehicle by which other disciplines are transported to their target audience. Against this backdrop, Orabueze (2016) illustrates that language is to literature what shovel, sand and water are to the mason (Lecture Note on Stylistics). Literary writers, therefore, manipulate language in literary texts in order to express what Adejare (1992) calls distorted reality. Hence, language could be said to be the sole medium of literature or literary discourse (Coulthard, 1985; Nnamani, 2014; Ogenyi \& Otagburuagu, 2014).

Considering the linguistic situation in Africa, and the place of English in Anglophone literature, writers of African prose fictions and other literary genres are in constant battle with English in order to express African experience. Meanwhile, the controversial statement made by Wali (1963) cited in Tucan (2012), as to the alienation of English in African literary texts had once triggered a serious debate between Chinua Achebe, a Nigerian novelist and Ngugi wa Thiango, a Kenyan literary writer. Achebe argues that English, the former colonial language should not be rejected entirely but accepted as part of a package which included many items of doubtful value. He, therefore, advocates for the nativization or domestication of English to carry the weight of native experience. This is why he (Achebe) writes in the English that reflects the Igbo culture even though the linguistic structures are grammatically aligned with that of Standard English. On the other hand, wa Thiango advocates for a total rejection of the English. This is because he sees English or any other European language as another means of spiritual subjugation. In fact, wa Thiango considers English as a "tool of neo-colonial oppression in creative work" (wa Thiango, 1981: 286). As though there is a contradiction, wa Thiango writes in Swahili but his texts are translated in English. This shows that English has a wider distribution of readership all over the world. Also, English provides lasting solutions to the problem of language complexities in Anglophone Africa.

Following Achebe's suggestion, Nigerian literary writers use the English language creatively to communicate various intentions. In fact, they twist the language to fit the culture and local sensibilities of the people. Yankson (as cited in Kadiri, 2014: 201) writes that "the creative artist expresses his sensations, perceptions, themes etc., primarily by the means of language. This perhaps explains why Agbasimalo 
carefully and deliberately uses language creatively to paint the mental picture of the Nigerian civil war in The Forest Dames. Orabueze (2016) avers that literary writers manipulate language to create scenes of war, crime, political and power struggles etc. The current study is, therefore, an attempt to explore language and style in Agbasimalo's The Forest Dames focusing on the author's choice of words and grammar which she used to express the plight of women in warring situations. Geoffrey Finch (as cited in Nweze 2012) argues that "every time we use language, we necessarily adopt a style of some sort; we make a selection from a range of syntactic and lexical possibilities according to the purpose of communication" (p. 4).

Stylistics is understood to mean "a method of textual interpretation which the primacy of place is assigned to language" (Simpson, 2004: 2). Widdowson (1975) defines stylistics as the interpretation of literary discourse from a linguistic perspective. As for Halliday (1967), it is the linguistic study of literary texts. Crystal and Davy (1969) view stylistics as a linguistic discipline that studies certain aspects of language variation. From the above scholarly definitions, stylistics in a nutshell, could be understood to mean the linguistic study of style.

Stylistics and styles are sometimes used interchangeably. However, the striking difference between stylistics and style is that the former studies the latter as we have already seen; although, one may not discuss stylistics without mentioning style. 'Style' in a general sense, is the way or manner of doing something. Historically, the term comes from the Latin word 'stylus' meaning a pointed instrument for writing on wax tablets. To the linguist, style is viewed as a distinctive or particular characteristics which enable us recognize the work of a particular writer by making a careful examination of his writing, word choice, word order etc. as markers of his personality. Leech and Short (1981) view style as linguistic characteristics of a particular text. Nnamani (2014) further sums up by explaining that " a creative artist expresses his feelings, thoughts, ideas and vision through language and his unique way of using language to convey his feelings is what is called style" (p. 35).

\section{The Statement of the Problem}

First and foremost, there exist countless literary evaluations by scholars, especially literary critics, on creative works by African female writers. Hence, a good body of literature and other critical studies in feminist stylistics exist. Secondly, celebrated African female writers such as Chimamanda Adichie, Buchi Emecheta, Zainab Alkali, Amma Darko, Kaine Agary, to mention just these, had received much literary and linguistic attention. Thus, it appeared as if there was some sort of alienation and conspiracy; a contemporary female writer like Agbasimalo who has three literary works to her credit has scarcely been given any serious linguistic attention. In fact, to the best of the researchers' knowledge, her works are yet to receive linguistic appraisals. Yet, Agbasimalo is a writer whose choice of words and sentences helps to convey her message clearly to the readers. So, as an upcoming creative writer, there is the need to stylistically analyze her works from the viewpoints of linguistics so as to identify the prevalent stylistic features at lexical and grammatical levels that she uses as her style index to convey her message. This problem, therefore, informs the researchers' desire to attempt a lexico-grammatical analysis of Agbasimalo's The Forest Dames.

\section{The Aim and Goals of the Study}

Stylistics is a viable enterprise in the study of language. This study, therefore, aims to achieve the following:

I. To identify the prevalent linguistic tools at the levels lexis and structure used by the author as a style index to convey the message of the novel.

II. To discuss logically how the tools contribute to theme and plot developments in the novel.

\section{Biography of the Author}

AdaOkere Agbasimalo has a degree in French from the University of Nigeria, Nsukka. She obtained her Master's degree from University of Lagos where she studied International Relations. She is currently defending her doctoral papers in University of Nigeria. Agbasimalo had authored three novels in all. The first was Bow You Must, followed by Waves of Destiny and The Forest Dames. She is also a recipient of different awards: Award of the Extraordinary Woman by Genevieve Magazine, Merit Award of Excellence by Nigerian Association of Women Journalist and UN Eminent Peace Ambassador. This perhaps explains why she entitled her last novel The Forest Dames.

\section{The synopsis of the novel}

Agbasimalo's The Forest Dame is a fictitious account of the Nigeria-Biafra War and its double negative effects on women who appear to be mostly hit in every warring situation. Agbasimalo fictionalizes the characters with the hope of driving home the message of the futility of war and its double effects on women and children. This was truly the state of Nigeria from 1967 to 1970.

Agbasimalo explicates the plight of women and teenage girls in warring times through the characters of Deze, the heroine in the novel, Gonma, Sopuruchi and Lelenwa. This set of girls display physical courage and psychological strengths amidst hardship, suffering and death orchestrated by the civil war. Their actions are, however, unconnected with their quest to maintain purity, chastity and better still, avoid being sexually molested by the invaders, the Nigerian troops. So, with the help of Mrs. Phoebe Ofoegbu and Mrs. Dora Buno and with the special God's intervention, the girls who Agbasimalo refers to as the Forest Dames, find themselves in a hideout in the forest which further exposes them to the danger of being devoured or harmed by the wild beasts of the forest and restless evil spirits. However, the dames choose to be devoured by the beasts if that is the last option; just to maintain the purity of their innocence.

AdaOkere Agbasimalo is a creative artist who has demonstrated dexterity at various levels of language in The Forest 
Dames in order to exploit various styles to communicate the emotions of the characters in their novels. She remains highly selective in her choice of words in order to send across the central message of the novels to their audience. She is a fairly new literary writer who paints the mental picture of the universal truth in her novel. As a contemporary writer, she writes to satirize the societal happenings without actually hurting anyone. She justifies this assertion in this novel as she recount the futility of war and its effects on women and children. Consequently, the study examines the linguistic stylistic analysis of Agbasimolo's The Forest Dames.

\section{REVIEW OF RELATED STUDIES}

Dutta (2010) explored the use of language and style in Achebe's Arrow of God. The paper aimed to examine Achebe's manipulation of language to bear the burden of native experience. The findings revealed that the author explored language through the use code-switching and code-mixing, Pidgin English, proverbs, songs, humour, satire irony etc. to capture the true state of Nigeria in the 1920s. Dutta concluded that Achebe explored various possibilities of English to carry Nigerian experience in the pre-colonial time. In a similar way, Kadiri (2014) investigated style and language in Nigerian novels, taking Otagburuagu's Echoes of Violence as the source of primary data. The findings showed that the author used the stylistic elements of well-arranged plot, omniscient narrator, foregrounding and characterization to echo his message. Also, sentences that violate category rules and selectional restriction rules were deployed to foreground the themes of suffering, marginalization and victimization in the novel. Ogbodo (2014), on his part, worked on transliteration and code-switching as elements of style in Nigerian prose fiction. Three texts were examined: Men without Ears, Eaters of Dust and Noble Mistress. It has been discovered that the authors of the three texts employed code-switching and transliteration in their books to give them Nigerian flavor.

Büşra (2014) conducted a study on a comparative stylistic analysis of Hurston's Their Eyes were Watching God and its Turkish interpretation; focusing on the theory of foregrounding as the analytical tool. It was found that the author used dialect as foregrounding stylistic device in the source novel to draw the readers' attention to salient points; however, in the target novel (Turkish translation), he does not fully show the use dialect because the Turkish language does not have equivalent dialectal properties with that of Africa. In Putri's (2011) stylistic analysis of Spark's Dear John, he found, through a quantitative approach that the commonest figure of speech used in the text were grouped into three: figure of comparison, contrast and association. The author further expressed the meanings of these figures of speech literary in the said text. In Dean's (2010) contribution to stylistic knowledge, he conducted a study on stylistic analysis of Okpenwho's The Last Duty and Habila's Waiting for an Angel. The general objective of the study was the examination of prose fictions using linguistic tools in order to show the existence of literary language and how language is skillfully used in literature. Comparative analysis and theory of Marxism were adopted as the theoretical frameworks of the study.
The results showed that coinages, reduplications, borrowing, parallelisms, and sentences that violate selectional restriction rules were deployed in the texts. So, literary language which is distinct from everyday language exists.

Okebalama (2014) investigated style and language in Chukwuemeka Ike's Conspiracy of Silence in order to find out the workings of language in the text. The study revealed that figurative language such as idioms, metaphor, rhetorical questions, repetition, proverbs, euphemism, dialogue, the use of Hausa, Igbo and Yoruba words, constituted the elements of style which the author used in driving home his message. Wijitsopon (2013) studied the corpus-based style in Jane Austen's novels. Six major novels of the author were selected to examine the usefulness of this method in interpretation literary texts. It has been found that the corpus-driven model could provide useful results in supporting and refining the author's work. Finally, Amaechi (2012) studied Adichie's Half of a Yellow Sun and Ezeigbo's Trafficked from a linguistic stylistic viewpoint using the theory of Mikhai Bartin's contemporary rhetoric to support its analysis. It was, however, discovered that both authors used rhetoric in their novels to evoke emotions.

In conclusion, the works reviewed are similar with the current study in that they are both stylistic readings of novels. However, the current study differs from others in that it specifically examines language and style in Agbasimalo's The Forest Dames, Focusing on the author's choice of words and sentences. This is, therefore, the gap which this study intends to fill; considering the dearth of studies in the text.

\section{THEORETICAL AND METHODOLOGICAL FRAMEWORK}

The study adopts Geoffrey Leech and Mick Short's (2007) Checklist of Linguistic and Stylistic Categories as the analytical tool. Leech and Short (2007) propose an analytical template for doing linguistic stylistic analysis of texts, which they technically referred to as 'checklist'. This theory was first propounded in 1981 and updated in 2007 in their book entitled Style in Fiction Second Edition. According to Leech and Short (2007), "every stylistic analysis is an attempt to find the artistic principles underlying a writer's choice of language" (p. 60). They argue further that all texts and writers have individual qualities and these qualities are what call the attentions of stylisticians in order to select what is significantly dominant in texts. The checklist is, therefore, a useful tool for doing a linguistic stylistic analysis.

Leech and Short (2007) place stylistic categories under four headings: lexical categories, grammatical categories, figures of speech, and cohesion and context. They deliberately omitted the semantic categories from the checklist because they assume that it is easier to arrive at these categories through other categories. For example, "we use lexical categories to find out how choice of words involves various types of meaning" (p. 61). It is important to reiterate the fact that this list is heuristic; and it is no crime to mix categories. So, categories are bound to overlap so that the same feature may appear under different headings/categories.

The study adopts the Descriptive research design because the design focuses on the discussion of conditions or 
elationships that exist between phenomena in order to describe, compare, contrast, classify, evaluate, analyze or interpret entities or events. It is noteworthy that this design is both analytical and interpretative in nature; so this choice is informed by the researchers' quest to analyze and interpret the author's choice of the linguistic features used in the text in order to drive home the central messages of the novel. The data of this study were extracted from Agbasimalo's The Forest which contains 303 pages. The researchers achieved this through a careful and repeated reading of the text. The researchers went from page to page; chapter to chapter to scan for the prevalent linguistic features, lexis (diction) and grammar (morphology and syntax). Data were analyzed qualitatively using Leech and Short's checklist, under two broad headings (i) lexical level and (ii) grammatical level.

\section{DATA ANALYSIS}

\section{Lexical Categories}

The authors' choice of vocabulary is examined under the lexical categories as postulated by Leech and Short (2007). Agbasimalo's choice of vocabulary is simple and semi-formal. In general, the words used in the novel are relatively easy to decipher because she chooses to write for everybody who has the ability to read. However, in some instance, she employs some technical words such as pogrom, undulating, discerned, shelling, startling etc. in order to give the texts a sense of variations. In some instance, informal expressions such as Morn Sir, follow me quick, no worry etc. are used to indicate the social and academic statuses of some characters. It is also important to emphasize that most of the words that the writer employs in the texts are expressive and descriptive in nature. These words are used to express the unfolding of events in the novel. Others are used to describe the characters, settings and the actual event. In facts, words are used to create the scene of war and its effects on women and children.

\section{Nouns}

Traditionally, a noun names a person, place thing, idea. In other words, it is a word or group of words used as the name of a class of people, places, or things, or of a specific person, place or thing. In the text, the author uses considerably good number of nouns to drive home the themes of war and its effects on women and children. Since a noun names persons, places, things and ideas; all the characters together with the things they interact with in the novels, are all nouns. We shall make specific the kinds of nouns used by the authors and their effects in the discourse. They include:

\section{Concrete versus abstract nouns}

Good writers of prose fictions deliberately select words that solidify or concretize the objects or substance that are physically visible or touchable in order to give their literary piece a touch of reality. Agbasimalo deliberately deploys the use of concrete nouns in their novels to build up her story.
Some of the concrete nouns used include: water, river (25), shelter, sun, palm kernel oil (92), raffia tray, kolanut (122), fish, path etc. (nouns referring to nature). Bicycle, shirts (32), dagger, bags (24), kegs, seats, luggage etc. (nouns referring to things). women, children, family, girls, soldiers, corpse etc. (noun referring to people).

On the other hand, the author also uses considerably good number of abstract nouns in the novel to denote names of activities or state. For instance, Agbasimalo uses abstract nouns alongside other types of nouns. Some of them include: goodness (20), whisper (19), hope (30), tension (40), courage (87), frustration (249), patriotism (64), partnerships (33), starvation (86), sacrilege (186) etc. The authors deliberately and skillfully adopt these in encoding their themes.

\section{Collective nouns}

It has been observed that the author deliberately employs the use of collective nouns in the texts to represent group as unit. Orabueze (2014) supports this view when she avers that a collective noun refers to a group of people or a thing considered as a unit or an entity.

The Table 1 below shows that the author consciously and skillfully uses collective nouns. Some of these nouns are exemplified in bold prints in the Table 1 below. It could be said that the writer's choices of this noun are informed by variations in noun usages in prosaic works. This choice does not only add to the artistic beauty of the works but also helps in deepening the meaning of themes expressed.

\section{Compound nouns}

Agbasimalo also uses compound nouns to build up their stories. This type of noun is formed by joining two independent nouns to form one word. For example, Agbasimalo uses the following compound nouns: canoe-man, duty-post, funeral food, sunlight, self-esteem, fatherland, self-governance, football, bush corner, farmland, mass-killer, land-mine etc. It is, however, noticed that Agbasimalo uses all forms of compounding realizations such as open, solid and hyphenated compounds In forming open compounds, the words are placed apart by a allowing a space in between them; e.g. bush corner. To realize solid compounds, the two nouns are brought together; e.g. farmland, waterfall, headmaster etc. while in forming a hyphenated compound, a hyphen is placed between the two nouns; e.g. canoe-man, duty-post etc.

It is important to state that the author deploys other types of nouns in the novel but the nouns that are dominant, apart

Table 1. Collective nouns

i. The family was beginning to adapt to the new lifestyle (60)

ii. They should target only the military, Prof. (88)

iii. The presence of the delegation from Mboke, Ihiagwa, his mother's home, was especially conspicuous. (106)

iv. The warmth freely radiated by his family was enough to provide the answer to his question (202)

v. The girls watched the women melt into the thick forest (26) 
from proper and common nouns are concrete and abstract, collective and compound nouns. It is also noteworthy to state that the nouns perform vital functions in the development of the plots of the novels. For instance, the suffering, war, death and deprivations are givens various arbitrary names which are presented by characters (persons), properties (things), animals and ideas. Therefore, it is within the author's styles that these noun types are put to use.

\section{Verbs}

Verbs are lexical forms that must be present in any text whether literary or non- literary for the conveyance of meanings. Leech and Short (2007) are of the opinion that among the parts of speech, the verb carries or expresses the important most important part of meaning. In literary text precisely, the verbs are used to reach various themes. Traditionally, a verb is a word that indicates an action, a state or condition. Agbasimalo deploys different types and forms of verbs in their texts. However, the ones that are stylistically dominant are Dynamic and Stative verbs and, Transitive and Intransitive verbs.

\section{Dynamic verbs}

Dynamic verbs are verbs that indicate or express actions such as movement, physical acts and speech acts. Some of the words that indicate actions in the novels include:

vi. Grab: "Daze grabbed the bag, looked into it and felt relieved" (24)

vii. Eat: "The girls ate the food with relish and drank the water to their satisfaction" (25)

viii. Kill: "kill them, kill the bastards" (41)

ix. Leave: They left (41)

$x$. Pounce, pull and push: "The men pounced on them, pulling them up and forcefully pushing them out" (43)

xi. Wipe: "Wiping off the sweet with the edge of their wrapper and enduring the weight on their heads, they persevered and trekked on."

\section{Stative verbs}

Some of the stative verbs used in the text include Delight (27), See (15), Believe (23), Knew (19), Slumbered (19).

The author has successfully used the dynamic verbs to show different type of actions in the novel. For example, Agbasimalo uses the verbs kill, pounce, pull and push to express how lives were taken out of the Igbos in Kaduna during the pogrom. In same vein, the verbs eat and drink are used in page 25 to expressed how the mothers of forest Dames feed them in the forest during the war. The verbs wipe is used to express suffering experienced by mothers of forest Dames who trek miles to fend for the family. The verb 'left' is used to indicate movements during the exodus.

It could be observed that the writer does not only use the dynamic verbs but she also use a good number of stative verbs to indication condition or state. Some of the verbs are listed above. It is equally important to state that the verbs used show various actions, states and condition. They in- clude movements, perceptions, physical acts, speech acts, psychological states etc. It could also be observed that most of the verbs used are mostly in the simple past, past participle or past progressive tenses. Irrespective of the usages, the verbs carry the important parts of meaning.

\section{Transitive and intransitive verbs}

The author has also made a very good use of transitive and intransitive verbs in the texts. Transitive verbs take direct object while intransitive do not. Some of the transtitive verbs include:

xii. He pulled off his shirt, dropped it ... (32)

xiii. They picked up their begs and step out... (53)

xiv. ... the women stood and watched old canoes ferrying people across to the other side (74)

$x v$. She opened her eyes and dropped in the oil (92)

xvi. Jonas assisted his wife, Nkasi to put down her luggage...

Agbasimalo uses some of the following intransitive verbs: slumbered (19), live (28), sat (45), sped (64), walked (93) danced etc. The author uses these forms of verbs to express different actions and states. It is, however, observed that Agbasimalo uses more of intransitive verbs in her novels Be it as it may, the author's choice is informed by the fact that the verbs carry the most important aspect of meaning.

\section{Adjectives}

An adjective is a word used to modify, describe, restrict, or somehow qualify nouns and pronouns. Adjectives modify only nouns and pronouns; they do not modify other adjectives, verbs, or adverbs (Robbins, 2007). Adjectives generally describe nouns or noun equivalents; therefore, in the description, the adjective comes before or after the nouns. In the texts, the author employs descriptive adjectives and other forms of adjectives to describe the characters, scenes, events etc. These descriptions paint the mental picture of the characters or the scenes being described. In other words, it appeals to the imagery of sight, perception, smell, touch etc. Some of the adjectives used by the authors include Table 2:

Agbasimalo has used adjectives to describe colour, shape, quality, people, dreams, history, age, object etc. for example, Agbasimalo uses the word "black" to describe the beauty of Daze, the heroine of the novel. Similarly, she uses the word "swift" to describe the fast and invisible movement of the bomber jet that unleashes mayhem on the Biafran civilians. It is, therefore, right to say that the authors are exceptionally good at using adjectives in modifying nouns or pronouns.

Table 2. Adjectives

\begin{tabular}{ll}
\hline Half-filled (19) & Distant (28) \\
Youngest (22) & Trembling (22) \\
Regimented (28) & Surprise (67) \\
Pointed (30) & Swift (92) \\
Suffocating (87) & Nocturnal (20) \\
Black (beauty) (30) & Happy (25) \\
\hline
\end{tabular}




\section{Adverbs}

Adverb is another prevalent Part of Speech used by the author in their novel. It has been established that the verb carries the main part of meaning in a sentence; it is however, worthwhile to say that the adverbs helps in modifying the verbs. In other words, all adverbs serve as modifiers to verbs, adjectives or other adverbs. Adverbs can also modify clauses, phrases, and entire sentences. Adverbs indicate the how, when, where, and what (extent) of something. The author deploys adverbs to describe the actions, conditions or states of verbs in the novels. For example, some of these adverbs are used in the novels to modify verbs, adverbs and adjectives Table 3:

The author employs more of adverb of manner than any other adverbs in the text. For example, Agbasimalo the word "sparingly in page 25 to describe the manner in which the Forest Dames intend to use water in their hideout "They would have to use it sparingly so as not to run out before the next visit" (p. 25). Also she uses the word significantly to describe the reduction of danger in the pathway when the war was declared over "This time, they did not go through the hidden paths because the danger had been significantly reduced".

\section{Registers}

The dominant register/dialect used in Agbasimalo's The Forest Dames is the registers of war. Eyisi (2005) define registers as words used in different professions to explain certain technical devices or operations in the area.

The words in the Table 4 below are associated with Military versus military war game. The author uses this register with the show of dexterity. She deploys these words to create a scene of war and to paint a mental picture of warfare; more importantly, to express the themes

Table 3. Adverbs

\begin{tabular}{ll}
\hline Sparingly (25) & Significantly (231) \\
Slowly (33) & Gradually (55) \\
Sadly (34) & Ferociously (63) \\
Forcefully (43) & Tomorrow (177) \\
Tactfully (48) & Briskly (104) \\
\hline
\end{tabular}

of war. These choices of words are, therefore, considered formal and appropriate. According to Agbasimalo, the most sophisticate weapons used in the war belong to the Federal army while the Biafran army fights with no ammunitions. This is made clear in the words of one of the Biafran soldiers after the recapture of their territory by Federal troops: "Gosh! What a quick loss! It is so sad." "I wish we had enough ammunition. Who are they to push us out? It's their weapon. Their weapon pushed us out, not them (p. 136)

\section{Words associated with agony of war in the novel}

The expresses and describes the pains the Igbo suffer before and after the Nigeria civil war. These words create a visual imagery of the happenings which include movement, tension, torture and death. Some these words used in The Forest Dames include: selective killing (38), famished and thirty (39), dead bodies (40), fainted (44), dismembered bodies (67), food scarcity (70), canoe capsized (75), starvation (86), destruction (87) sobbing (93), and displaced people.

\section{Collocation}

Collocation is a linguistic term that refers to the classification or grouping of words according to the company they keep. Like human beings, words keep company; that is, words select their pairs accordingly. Yeibo and Akerele (2015) see collocation as the grammatical combination of lexemes. This combination suggest why words occur in the manner they do. In the novel, the author uses a good number of collocations to express, describe or argue certain themes or subject matters. Some of the words that co-occur include: Quality time (38), Hunger and starvation (86), Military camp (125), Enemy soldiers (136), Selective killings (38), Dead bodies (40) etc.

Some of the collocations are familiar; for example, the word paramount co-occurs with the word importance; but some other collocations are strange; for example, the word selective may or may not co-occur with word killing. The author however uses it to give literariness to the literary piece and also to foreground an important aspect of meaning.

Table 4. Register of military warfare

\begin{tabular}{llll}
\hline Army & Soldier & Retreat & Enemy's bullet \\
Combat-ready & Invade & Re-strategized & Advance \\
Air-raid & conscription & Trench & Shelling \\
Bombs & Makeshift bunkers & Couched & Bomber jet \\
Take-cover & Aircraft & war & Salute \\
Duty-post & Morn. sir & Guard room & Military vehicle \\
Recruit & Guard & Colonel & Military war game \\
Vandals & Rebels & Saboteur & Mortar bomb \\
Army sniper & Ambush & Sophisticated riffles & Atack \\
Retreat & Ammunition & Intruders & War general \\
\hline
\end{tabular}




\section{Pidginized words/expressions}

Pidgin, according to Decamp, cited in Eze (2014), is a communicative language borne out of incidence of multilingualism and which does not belong to everybody. Onuigbo and Eyisi (2008) add that Pidgin is meant to fill a special communicative gap as a compromise trade language. The language situation in Nigeria is a heterogeneous one because over 500 languages are spoken in Nigeria. Agbasimalo deliberately deploy pidginized words/expressions in order to allow for a free flow of communication among the Igbos, Hausa and other ethnic groups. This is seen in when Bulus uses Pidgin English to show appreciation for cash and meal offered by Mama Daze: I dey around any time you need me (p.33). The word dey belongs to lexicon of Nigerian Pidgin English. Another instance where Pidginized Expression is used in the novel is when Mama Gazu, a female trader wants to know the immediate cause of the crisis; she then engages Mama Daze in conversation: But Mama Daze, na how dis kain wahala start sef? (p.35). Also, Pidgin English is used in page 135 when the home soldiers killed the commandant and recaptured Nekede from Federal army; one of the home soldiers speaks thus: De Oga don go final... (p. 132).

In Nigeria, the language of soldiers is the Pidgin English. In fact, the type of Nigerian Pidgin English spoken in Nigerian army barracks is quite different from other varieties; and as such, soldiers use it skillfully. Agbasimalo puts this variety of Pidgin in consideration in the composition of her text. Below are some pidginized expressions to illustrate this: xvii. Hey! You! Ajuku tamatu, follow me quick (p. 162).

xviii. $\quad$ Na true you talk (p.163).

xix. I gwo kwom tumaro (p. 163).

xx. Hey, Idul cibilian, kwom here... shut up Ajuku cibilian! Tomuro you join army. Today I shoot your leg. No army for you (p. 195).

Agbasimalo goes further to represent the typical Hausa accents in the Pidgin English the Hausa soldiers speak "qwo, kwom and cibiian" instead of "go, come and civilian" respectively. We understand that the author chooses to use this reduced form of language to express the inhuman treatment meted on the civilians by the Nigerian army during the Nigerian civil war. We, therefore, conclude with Eze's (2014) submission that many African writers of literature use Pidgin in their various texts to assign roles to characters of lower educational statuses. Also, to show that Pidgin is functional and acceptable as a mark of style and therefore, it is not something to be dismissed in language studies.

\section{Code-mixing and code-switching}

African writers deliberately deploy the mixing and switching of codes in their texts in order to present the object, phenomenon or idea the way they actually are without any form of alteration; so that the semantic import would be retained. In the words of Ngonebu (2008), code mixing is an art of combining two codes or two languages to make a statement..." (p.16).She goes further to define code-switching as the situation whereby the speaker changes from one language or code to the other in narration. It is a known fact, therefore, that some native words or expressions do not have the exact or suitable forms that could be used in their steads. The writer will have no choice than to bring in that word/expression that will fill that void. In so doing, different native codes may have to be placed side by side with that of Standard English. The author deploys Igbo and Hausa codes in juxtaposition with English. Instances abound in the following expressions Table 5:

The author has stylistically deployed other codes such as Hausa and Igbo in the novels to add local flavours to the language use. For instance, in the novel The Forest Dames, Hausa words are used in pages 32, 41 and 195 as illustrated in the table above. The words wake refers beans; garirogo (cassava flour), kubewa (okro). Agbasimalo, as a mark of style, places the coded word alongside English for non-Igbo readers Table 6 .

Instances of code-switching are prevalent in both texts. For instance, Dora in page 123 argues that the ongoing war has made people to forget about tradition; that people care less about kola instead, they pray for the war to end. One of the listener who is quite convinced with Dora's argument, brands her a philosopher using the Igbo codes as illustrated in the table above. his is equally illustrated in the table above. Agbasimalo meticulously uses code mixing and code-switching as style markers in the text to drive home her various themes and to give every character the chance to air out their fillings.

\section{Grammatical Categories}

\section{The use of structural sentences in the novels}

\section{Simple sentences}

A simple sentence contains one finite verb and expresses a complete sense. This is perhaps why Eyisi (2005) explains that a simple sentence has only one main clause and one

Table 5. Code mixing

i. "Mama Daze, wake na seventeen, garirogo na twelve... dry kubewa na one (32)

ii. Nagode, Bulus (32) (Thank you Bulus)

iii. Ba kowa, nobody... (41) (No one is here)

iv. No army for you. Shegiya (195) (No army for you bastard)

v. Tank you nde red cross (150) (Thank you red cross members)

vi.Kedu? Odi nma, umunna m (53) (How are you my brothers?)

vii. Julie nwanne m, you must take heart (152) (Julie, my sister, you must take heart)

viii. I hope they will give me more of other items and less of that otogirigiri... (207) (sweet)

ix. "okwe, game, "Udunna answered (Game)

Table 6. Code-switching

x. This is true. You are right. Mama Dorati, i wu kwa filosofa! (123)

xi. Aha m wu Julie Ejema. Kenma out onwa, ka nwaakiri m ji ataga ahu. Ya nyuo, ya agboo agboo (146)

xii. I mee na, Nwarie (169) 
finite verb. Agbasimalo deploys a good number of simple sentences in this novel. For example, the following simple sentences are used in the novel:

xiii. The forest dames had waited anxiously for another nocturnal visit (p.19).

xiv. The brooding darkness simmered with sound of the wind (p. 20).

$x v$. People ran in different directions (p.87).

$x v i$. The masquerade danced systematically (p.107).

Each of the sentences contains one finite verb. The verb waited in sentence one expresses how patiently and anxiously the girls have waited for their mothers to visit again. The verb simmered expresses the solemnity of the environment. Others verbs identified in this category express just one idea. The author chooses to use simple sentences in the novel to express in clearer terms some events that need be forcefully expressed. If the authors have chosen otherwise, the semantic imports of the sentences would have been adversely affected.

\section{Compound sentences}

Eyisi (2005) defines a compound as a sentence composed of two or more independent clauses joined together by a coordinating conjunction or semi colon. The two authors deploy compound constructions to show variation in sentences used in the novels. Some of the compound sentences used in text include: xvii. Daughters, we are very well but Dennis' daughter was captured (p. 21).

xviii. The sometimes waylaid the women returning from the distant market and disposed them of their goods (p. 75).

xix. Many families returned; many did not (p. 56)

Sentence one above expresses two senses craftily joined in one sentence. The first is the Dora's response to their daughters' inquiry of the welfare of their relatives; while the second is a contradictory statement which informs the girl about the abduction of one of the endangered species. The other sentences also express two ideas in one sentence. The deployment of this sentence type adds to stylistic quality of the novels.

\section{Complex sentences}

A complex sentence contains a principal clause with one or more subordinate clauses. Eyisi (2005) adds that this sentence type is usually formed by subordination that is, combining two or more simple sentences making one of them more important than the other(s) and turning the less important one(s) into subordinate clause(s). The authors of the novel, has selectively used this sentence type to express two or more in-depth ideas by subordinating the less important ones. Some of the instances where complex sentences are used in the novel include:

$x x$. Deze's mother told the girls about an elderly man, Joseph, who was beaten to death because he tried to stop the uniformed intruders from taking his bicycle (p. 23).

In the sentence above, Agbasimalo craftily knits two ideas in one sentence. She, through the character of Dora, informs the girls about the murder of Joseph by Nigerian Soldiers. Also, she goes to explain that it is because he does not allow them to take his bicycle. The authors have demonstrated skills in using the three structural sentence types simultaneously in their novels to show sentence variations. They also choose to apply simple, compound and complex sentences in the novels in order to avoid monotonous expressions and also to show the differences in sentence lengths and strengths.

\section{The use of functional sentences in the novels}

Agbasimalo and has used declarative, interrogative and imperative sentences in her novel. A declarative makes a statement; an interrogative sentence poses a question while an imperative sentence issues a command or shows emotional expressions. The following are some instances where these sentences are used in the novels:

xxi. The forest dames had waited anxiously for another nocturnal visit. They had looked forward also to the rations always came with visit (p. 19). (Declarative sentence)

xxii. When will all this stop? Sopuru wondered aloud (p. 24). (interrogative sentence)

xxiii. Kill them, kill the bastard. Hey, young girl, this way, undress quickly! (p. 41). (imperative sentence)

The author has variedly use functional sentence types in both texts. She uses declaratives to elaborate the plots of the novel and also to give accounts of how several other events unfold. In sentence 1, we see how the mothers of the forest dames paid night visits to the dames in the forest. The author uses the characters in dialogic manners to pose questions in sentences 2 and 4. Sopuru asks a rhetoric questions without actually directing it to anyone as to when the war would end. In sentence 3, the author issues out command through the characters. During the pogrom in Kaduna, the leaders of the assailants issues out command that the Igbos should be raped and killed. In fact, the use of imperative sentences in the novel is deliberate because the army uses command in their operations.

\section{The use of active and passive voices in the novels}

The story in the novel is told using active and passive voices. Active voice tells you what the subject of the sentence does. In other words, it is in passive voice that the subject is assigned the agent role. In passive voice, the grammatical subject expresses the theme or patient of the main verb. Some of active and passive constructions used in the novel are as follow:

xxi. "Daze grabbed the bag, looked into it and felt relieved..." (p. 24).

xxii. The girls ate their food with relish and drank their water to satisfaction (p. 25).

In sentence 1 and 2, the subjects of the sentences are highly active and performative. Agbasimalo uses this voice to describe the action of 'Daze' and the 'girls'.

\section{The use of adverbial and adjectival clauses in the novel}

The author uses adverbial and Adjectival clauses to create special effects in the developments of the novel. An adjecti- 
val clause is a subordinate clause which qualifies a noun or pronoun in the main clause while an adverbial clause modifies a verb, an adjective or another adverb in the main clause. Instances are bound in the following sentences:

xviii. Sofuru's mother told the story of Ogechi, a mother of two, who was snatched from her husband while they were having dinner (p. 22). (adjectival clause) xix. The family was beginning to adapt to the new lifestyle when it was announced that a resettlement plan would be put in place for returnee civil servants (p. 60). (Adverbial clause of time)

In sentence 1 and 2 , the authors use the adjectival clause "who was snatched from her husband while they were having dinner" to qualify the noun Ogechi; thereby describing how this nursing mother is abducted by Nigerian troops for sexual pleasure. Similarly, in sentence 2 deploys adverbial clause of time and place to modify the verbs "adapt" in the main clause. It is pertinent to state here that adverbial clauses of time and place are preponderant in the text because the plots are historical in nature. More so, adjectival clauses are significantly dominant in the novels because the events require not only narration but also descriptions.

\section{The use of elliptical sentences in the novels.}

In the text, the author employs the use of elliptical sentences as markers of style. An elliptical sentence is s sentence whose subject or the predicate is omitted but it is understood in context. The following are instances where elliptical sentences are found in the texts:

$x x$. Kill them, kill the bastard (p.41).

xxi. "Nobody"

"Under the chair."

"Nothing."

"Behind the door, everywhere" (p. 46). xxii. "Nekede and you? (p. 48).

In the sentence 1, Agbasimalo deliberately omits the subject of the sentence (you). It is however understood that she means "You should kill them, you should the bastards." In the second sentence, it is also understood that "Nobody" means that "there is nobody" in the room which searched thoroughly for Igbo victims. So, the first part of the sentence is omitted but it is understood in context. The other sentences also fall in line with the ones we have analyzed; however, in sentence 3 "Nekede and you? " It is understood to mean that "I am from Nekede and where are you from?" However, the remaining part of the sentence is omitted as noted above. This is also considered as a style marker of the texts.

\section{The use of inverted sentences in the text}

An inverted sentence is a sentence that is constructed with the subject taking the predicate position and vise visa. The author employs the use of this sentence type in their texts. For instance, Agbasimalo uses it to describe Deze, one of the forest dames, as the youngest. The sentence below illustrates this:

xxiii. "Of the four girls, Daze was the youngest" (p. 27).

The sentence above could as well be put thus: "Daze was the youngest of the four girls."
Agbasimalo also uses elliptical sentence to express Justin's ill-feelings about the birth of Gonma, his female child. He has earlier expected a male child but to his disappointment, Gonma is brought forth. The sentence below shades more light on this:

xxiv. "When Gonma was born Justin's pride was brutally battered" (P.85).

The sentence could be rewritten thus: "Justin's pride was brutally battered whaen Gonma was born.”

\section{Summary of Major Findings}

Language could be fascinating and thrilling if it is used creatively. This is made clear in Agbasimalo's text, The Forest Dames. Nnadi (2010) establishes that a creative writer demonstrates this skill only through creative or imaginative use of language. A writer is, therefore, adjudged good or bad through his or her style.

First, Agbasimalo has shown high level of dexterity in this text through the network of her lexical choice. Generally speaking, her lexical selection makes the text highly readable, comprehensible and enjoyable. We could confidently say that the writer uses more of the major parts of speech (noun, verb, adjective and adverb), as a style index, to concretize the message of the negative effects of war on women and children. Although, it is practically impossible for any writer to write without using these parts of speech, but Agbasimalo's deployment of these word classes in the text is timely and appropriate. Hence, it is found that nouns take the largest share of the word classes. These nouns play germane roles in naming characters, places and events. Similarly, verbs are found to describe actions and states in the novel. For example, the verbs 'kill', 'slaughter', 'smash' etc. explicate the agonies suffered by the Igbos during the pogrom. Adjectives are also found to perform various descriptive roles, thus, the writer uses this word class to appeal to the five human senses. Adverbs are deployed as well to perform various semantic functions in the text.

More so, the author is very conscious of the text's time-setting, hence, the military register deployed in the text denominates other specialized words and vocabulary; considering the fact that the text is set during the Nigerian civil war. Her choice of this register type is informed by her quest to vividly paint the mental picture of the scene of Nigerian civil war using language. Not only that, the word choice evokes strong emotional feelings on the reader because they see and feel the negative effects of the civil war through the words. Similarly, words associated with suffering and agonies are deployed by the writer to complement the military register and also to give the text a touch of reality.

It was also found that Agbasimalo is creative in using collocations in the novel. She consciously selects and marries words together for aesthetics purposes. Words such as 'selective' and 'killing' should not ordinarily co-occur; but the writer skillfully creates these strange collocations in order to make the text pleasurable to the reading populace. Another area where Agbasimalo demonstrates that she is highly creative is in the area of mixing and switching of codes and the use of pidginized words/expression. Igbo codes tend to 
dominate other native codes; probably because most of the actions unfold in the South-Eastern Nigeria. Similarly, Agbasimalo deploys pidgin in the text so as to involve some characters who do not have the mastering of the Standard English into dialogic communication. For example, Bulus, the market women and the Nigerian soldiers used pidgin to communicate. Although,Pidgin is considered to be the language of soldiers in Nigerian context.

At the sentence level, Agbasimalo deploys sentences according to structure and sentences according to function to develop the storyline of her novel. Precisely, she makes dominant use of simple sentences in the text to pass across her message unambiguously. Compound and complex sentences were also deployed in order to give the text a sense of variation and of cause, to avoid monotonous movement of tone. It was also found that the author tactically deploys more of declarative sentence together with interrogative and imperative in the novel. This is because the text is narrative. Thus the variations in sentences give the text a linguistic balance. So this choice is timely and appropriate. It is, however, important to state that Agbasimalo's sentence choices aid in theme and plot development of the novel. To buttress the importance of variation in sentences, Agbasimalo imports inverted and elliptical sentences in order to stylistically express language variation in literary discourse. Last but not the least, adverbial clauses are found to be dominant in the text. Adverbial clauses of time, place and manner seem to be at the forefront. The author deploys more of these clause topologies to slow the movement of sentence. In other words, they are deployed to control the speedy movement of events in the text. However, this clausal knitting does not create a barrier in assimilating the message of the novel.

\section{CONCLUSION}

The importance of language in creative works can never be overemphasized. This is why creative writers manipulate language in various possible ways to deliver their message to their target audience. Just like other celebrated African female writers, Agbasimalo has demonstrated that she could creatively use language in her text, The Forest Dame to pass across the message of hostility of war and its effects on women and children. So, through this scientific inquiry and through the various ways that the author has manipulated linguistic resources such as word classes, language register, code-mixing and code-switching, pidginized words and expressions, clausal typology and sentence types, to thematize the message of the text and to develop the plot of the novel. These linguistic tools identified contribute immensely to project the overall message of the text. We, therefore, adjudged her a good writer considering the fact that her style or use of language is simple and exquisite. It has been demonstrated that Agbasimalo's The Forest Dames could be stylistically analyzed from the viewpoint of linguistics, focusing on her choice of words and sentences. We repeat that the author is an excellent writer who is meticulous in her use of language. She uses it skillfully to drive home the message of the hostility of war and its negative effects on women and children. Specifically, her choice of words and grammar is appropriate in time and space because it used to unburden the experience of Nigerian civil war. In a nutshell, Agbasimalo exhibits high level of creativity in crafting her novel. We, therefore, recommend that scholars should carry further studies on the following:

a) Grapho-phonological Foregrounding in Agabasimalo's The Forest Dames.

b) Context and Cohesion in Agbasimalo's The Forest Dames.

c) Literary Stylistic Analysis of Agbasimalo's The Forest Dames.

\section{ACKNOWLEDGEMENTS}

We thank immensely all those who had made contributions in this work; especially the contributing figures in Stylistics. We are grateful to you.

\section{REFERENCES}

Abioye, T., \& Ajiboye, E. (2014). A Lexico-Stylistic Analysis of Kaine Agary's Yellow- Yellow. In E. Arua, T. Abioye \& K. Ayoola (eds.), Language, Literature and Style in Africa, A Festchrift for Professor Christopher Olatunji Awonuga (pp 3-5). New Castle: Cambridge Scholars.

Adejare, O. (1992) Language and Style in Soyinka: A Systemic Textlinguistic Study of Literary Idiolect. Ibadan: Heimann Education Books (Nigeria) Plc.

Agbasimalo, A. O. (2014). The Forest Dames: An Account of Nigeria-Biafra War (1967- 1970). Lagos: Parresia Publishers.

Amaechi, A. C. (2012). Linguistic Stylistics in Chimamanda Adechie's Half of a Yellow Sun and Akachi A. Ezigbo's Trafficked. A Master's Project in the Department of English and Literary Studies, University of Nigeria, Nsukka.

Büşra, U.I. (2014). Foregrounded: a Comparative Stylistic Analysis of Their Eyes were Watchhing God and its Turkish Translation. Procedia- Social and Behavioural Sciences, 158, pp. 37-40.

Coulthard, M. (1985). An Introduction to Discourse Analysis ( $2^{\text {nd }}$ ed.). In C.N. Candlin (ed.), Applied Linguistics and Language Study. London and New York: Routledge.

Crystal, D. and Davy, D. (1969). Investing English Style. New York: Longman

Dean, O. (2010). A Stylistic Analysis of Isidore Okpewho's The Last Duty and Helon Habila's Waiting for an Angel. A Thesis Submitted to the Department of English and Literary Studies, Faculty of Arts, University of Nigeria, Nsukka.

Dutta, D.C. (2010). Bearing the Burden of Native Experience: A Stylistic Analysis of Chinua Achebe's Arrow of God. Rupkatha Journal on Interdisciplinary Studies in Humanities, Vol. 2, No. 2, pp. 163-164.

Eze, V.O. (2014). The Functional Role of Pidgin in Nigeria: A Stylistic Study of Selected Literary Works. In E.J. Otagburuagu, L.C. Ogenyi \& J.C. Ogbodo (eds.), Exploration on Styles, Stylistics and the Language of Literature. Enugu: Benak Publishers. 
Eyisi, J. (2005). The Sentence. In S. Onuigbo (ed.), English Language: A Grammatical Description. Nsukka: Afro Orbis Publishers.

Halliday, M.A.K. (1967). Notes on Transitivity and Theme in English: Part 1. Journal of Linguistics, Vol. 3, pp 192-200.

Kadiri, G.C. (2014). Style in the Nigerian Novels. In E.J. Otagburuagu, L.C. Ogenyi \& J.C. Ogbodo (eds.), Exploration on Styles, Stylistics and the Language of Literature. Enugu: Benak Publishers.

Leech, G., \& Short, M. (2007). Style in Fiction: A Linguistic Introduction to English Fictional Prose (2 ${ }^{\text {nd }}$ ed.) Great Britain: Pearson Education Limited.

Ngonebu, C.L. (2008). Fundamentals of Second Language Learning. Nsukka: Afro-Orbis Publication Ltd.

Nnamani, F. U. (2014). Linguistic Devices in Stylistics. In E.J. Otagburuagu, L.C. Ogenyi \& J.C. Ogbodo (eds.), Exploration on Styles, Stylistics and the Language of Literature. Enugu: Benak Publishers.

Nweze, E.U. (2012). Stylistic Study of Ngugi WA Thioango's Wizard of the Crow and Okri's The Famished Road. A Master's Project in the Department of English and Literary Studies, University of Nigeria, Nsukka.

Ogbodo, J.C. (2014). Transliteration and Code-Switching as Elements of Style in Nigerian Novels. In E.J. Otagburuagu, L.C. Ogenyi \& J.C. Ogbodo (eds.), Exploration on Styles, Stylistics and the Language of Literature (pp.106-115). Enugu: Benak Publishers.

Ogenyi, L. C., \& Otagburuagu, E. J. (2014). Stylistics and the Language- Nexus Literature. In E.J. Otagburuagu, L.C. Ogenyi \& J.C. Ogbodo (eds.), Exploration on Styles, Stylistics and the Language of Literature. Enugu: Benak Publishers.

Okebalama, U.N. (2014). Style in the Novel-Conspiracy of Silence.In E.J. Otagburuagu, L.C. Ogenyi \& J.C. Ogbodo (eds.), Exploration on Styles, Stylistics and the Language of Literature (280-290). Enugu: Benak Publishers.
Okoro, P.A. (2014). Style in Language in Oral Literature: A Study of Tales from Igbere. Masters Project Submitted in the Department of English and Literary Studies, University of Nigeria, Nsukka.

Onuigbo, S., and Eyisi, J. (2008). English Language in Nigeria: Issues and Development. Nsukka: Global Publishers.

Orabueze, F. O. (2005). The Major Parts of Speech in English langage. In S. Onuigbo (ed.), English Language: A Grammatical Description. Nsukka: Afro Orbis Publishers.

_ _ _ (2016). A Lecture on Stylistics (Unpublished). University of Nigeria, Nsukka.

Putri, E.P. (2011). An Analysis of Stylistics in Dear John Novel by Nicholas Sparks. A Thesis Submitted to Letters and Humanities Faculties, State Islamic University Syarif Hidayatullah.

Robin, R.H. (1980). General linguistics: An Introductory Survey. London: Longman.

Robbins, L. A. (2007). Grammar and Style at your Fingertips. USA \& England: Penguin Group

Sapir, E. (1921). Language: An introduction to the Study of Speech. New York: Harcourt, Bracee and Company.

Tunca, D. Towards a Stylistic Mode for Analyzing Anglophone African Literatures: Preliminary Epistemological Considerations and a Case Study. In J.K.S. Mokakha, O. John \& R.W. Pavlow (eds), Style in African Literature: Essay on Literary Stylistics and Narrative, pp.2-3

Wa Thiango, N. (1981). The Language of African Literature: Decolonizing the Mind: The Politics of Language in Africa Literature. London: James Currey.

Widdowson, H. G. (1975). Stylistics and the Teaching if Literature. London: Longman.

Wijitsopon, R. (2013). A Corpus Based Study of the Style in Jane Austen's Novels. MANUSYA Journal of Humanities Regular, pp. 41-44.

Yeibo, E., \& Akerele (2015). A Lexico-Semantic Reading of Chimmanda Adichie's Purple Hibiscus. International Journal of Language and Linguistics, Vol. 3, No. 2 pp. 144-155. 